\title{
European Systemic Risk Board in Legal and Economical View: Empirical Analysis in Front of Theory-Cal Analysis
}

\author{
Prof.Assoc. Dr.Alba Robert Dumi \\ Director of Graduate School, Business Department, "Ismail Qemali" University Vlore, Albania \\ Economy Faculty, Business Department, Tirana, Albania \\ Ma sc. Isuf Jahmurataj \\ PhD Students, South East European University, Faculty of Low, Civil low Direction
}

\section{Doi:10.5901/mjss.2015.v6n1p176}

\section{Abstract}

\begin{abstract}
This study examines the legal framework for municipal governance and analyses whether, in practice, the relationships follow the pattern as intended in the law. But, today there is growing recognition of the important role that community-based organizations (CBOs) can play in supporting young people's postsecondary aspirations and success Business takes place worldwide, in a huge diversity of societies and between widely varying organizations. Actually, the business environment has become more complex, with expanding and deepening ties between societies and between the many organizations within those societies. Moreover, many large organizations now see themselves as truly global in scope, not rooted in any one society. This study empirically examines the impact of debt management policies on borrowing costs incurred by state governments when issuing debt in the municipal bond market and it is in focus of public administration reforms.
\end{abstract}

Keywords: EU negotiated; roles of governments; European Community; International environment

\section{Introduction}

The aim of this article is to present an overview of the international environment, highlighting the differing levels, from local and national, to regional and international. Assessment of the Municipal Governance Situation

Municipalities want to know what activities they can do on their own without restriction, and further which activities require approval from above, or which are the responsibility of provincial government, but for which municipalities must be consulted. They want to be able to address public needs as expressed by their residents, either by having the full responsibility to do projects, or by having the right to participate and be consulted on all work in their jurisdictions.

And, of course, they want to know how services and projects are to be funded.

The European Union (EU) is an economic and political union of 28 member states that are located primarily in Europe. The EU operates through a system of supranational independent institutions and intergovernmental negotiated decisions by the member states. Institutions of the EU include the European Commission, the Council of the European Union, the European Council, the Court of Justice of the European Union, the European Central Bank, the Court of Auditors, and the European Parliament. The European Parliament is elected every five years by EU citizens.

The EU traces its origins from the European Coal and Steel Community (ECSC) and the European Economic Community (EEC), formed by the Inner Six countries in 1951 and 1958, respectively. In the intervening years the community and its successors have grown in size by the accession of new member states and in power by the addition of policy areas to its remit. The Maastricht Treaty established the European Union under its current name in 1993. The latest major amendment to the constitutional basis of the EU, the Treaty of Lisbon, came into force in 2009.

The EU has developed a single market through a standardized system of laws that apply in all member states. Within the Schengen Area (which includes 22 EU and 4 non-EU states) passport controls have been abolished. EU policies aim to ensure the free movement of people, goods, services, and capital, enact legislation in justice and home affairs, and maintain common policies on trade, agriculture, fisheries, and regional development. Unfortunately, the current legal framework lacks clarity on both the functions and revenue sources permitted municipalities under law.

The Law of Municipalities 1379 (2000), while seemingly permitting a wide array of functions, qualifies almost every use: municipalities can "take measures towards participation in construction" or do xyz "according to the law", or "through relevant offices", or "based on relevant regulation". While the current Law of Municipalities does not mentioned municipal 
revenue sources, the City Charges Act lists 83 fees/user charges/taxes, which municipalities may collect, thus addressing the issue indirectly.

However, we have heard from municipalities who have tried to collect revenues based on the list and who have had their efforts rejected out of hand by higher levels of government. The level of confusion about the roles, responsibilities and revenues of municipalities is considerable.

The discussion focuses on the main identifying features of the business organization, including ownership and decision-making structures, as they adapt in differing geographical contexts. It is emphasized that the multinational enterprise (MNE), central to international business activities, covers a variety of organizations, large and small and the growing interactions between organizations, governmental and societal players are resulting in a broader view of the business organization in society. Clearly there is a disconnect between the law as written and the reality on the ground. More importantly, the criteria in the current law may not reflect the desires of small communities to have the representation and empowerment to solve their own problems which comes with their designation as a municipality. This argument looks at varying perspectives on globalization, often argued to be the defining characteristic of our times.

\subsection{What are community-based organizations and why are they important?}

CBOs are public or private, nonprofit organizations engaged in addressing the social and economic needs of individuals and groups in a defined geographic area, usually no larger than a county. The college access and success efforts of CBOs vary, depending on their mission and vision. For example, direct service organizations provide college information, advice, and application assistance to individual students and families; organize college awareness workshops, financial aid nights, and college fairs; and support students in high school through their college years.

H1. Youth development organizations often offer extended learning opportunities such as traditional after-school activities with an academic focus, apprenticeships and internships, summer enrichment and travel, and activities on college campuses.

The analysis of the existing organizational structure of Municipality identified a number of deficiencies that could be addressed in a capacity building approach focused on: department restructuring reorganization of personnel assignments based on functional needs and to-be-developed job descriptions capacity building including training to enhance the skill sets of department managers and staff focused initially on techniques to improve revenue collection and solid waste management services.

The intent of this initial limited capacity building approach is to gain an early buy-in of municipal government officials through efforts that could achieve early success. There is, however, a need and an expressed interest for a more comprehensive capacity building program that could provide technical assistance, training, mentoring, and systems development to supplement the initiative.

Municipalities have few support systems and facilities to do the work they are responsible to do.

With several exceptions, the cities we have visited have no computers or management information systems, no service delivery equipment, few vehicles, and often no electricity in the dilapidated offices in which they work. Support programs are vitally needed. Integrated student services organizations work with schools to identify and assist individual students needing support with academic issues and non-academic problems that interfere with their school achievement averaging resources from appropriate agencies, including health care, social services, and counseling. Finally, community mobilization coalitions consist of public and private entities focused on systemic change to achieve an overarching community-wide goal such as doubling the number of high school graduates or improving college completion within a specified time period. (Source: Root Cause, Colliner A, 2011)

\subsection{EU and Maastricht Treaty legally organize}

The creation of a European single currency became an official objective of the European Economic Community in 1969. However, it was only with the advent of the Maastricht Treaty in 1993 that member states were legally bound to start the monetary union no later than 1 January 1999. On this date the euro was duly launched by eleven of the then 15 member states of the EU. It remained an accounting currency until 1 January 2002, when euro notes and coins were issued and national currencies began to phase out in the euro zone, which by then consisted of 12 member states. The eurozone (constituted by the EU member states which have adopted the euro) has since grown to 18 countries, the most recent being Latvia which joined on 1 January 2014.

All other EU member states, except Denmark and the United Kingdom, are legally bound to join the euro when the convergence criteria are met, however only a few countries have set target dates for accession. Sweden has 
circumvented the requirement to join the euro by not meeting the membership criteria.

\subsection{Organizing the Effort by Developing a Management Team and Partnership Network}

- Mayor and the body of councilmen must take pride in knowing their community and its residents.

- Community goals/image is constructed and must be visible to members of the community.

- Level of Organization and Full Democratic Representation: Representative organizations are necessary to serve as a forum for persons to give input. It is also important to determine the interests of each segment of the population.

- Political Will: Local authorities must demonstrate the political will to carry out the plan, i.e. A readiness to set objectives and to accomplish them.

- Availability of Basic Resources: Resources and funds are necessary.

- Objectives achieved and assumed by the population: The organization needs to have ownership of achievable objectives that combine individual interests with those of the community.

- Social sector defined in and for each objective: Each development objective has to have its social subject defined.

- Schedule of Activities: The plan must be concrete, with dates and deadlines set in advance and publicly announced.

- Permanent Evaluation: The performance, accomplishments, progress and failures must also be public to lay the foundation for new objectives and participation practices.

Information and Transparency: Information is the most secure basis for transparency in public life.

The euro is designed to help build a single market by, for example: easing travel of citizens and goods, eliminating exchange rate problems, providing price transparency, creating a single financial market, price stability and low interest rates, and providing a currency used internationally and protected against shocks by the large amount of internal trade within the euro zone. It is also intended as a political symbol of integration and stimulus for more. Since its launch the euro has become the second reserve currency in the world with a quarter of foreign exchanges reserves being in euro. The euro, and the monetary policies of those who have adopted it in agreement with the EU, are under the control of the European Central Bank(ECB).

\section{The Importance of this Study}

This study empirically examines the impact of debt management policies on borrowing costs incurred by state governments when issuing debt in the municipal bond market. Based on positive political theory and the benefit principle of taxation, it is proposed that states that adhere to best practice debt management policies transmit signals to the credit ratings, investment community and taxpayers that the government should meet its obligations in a timely manner, resulting in lower debt costs. The ECB is the central bank for the euro-zone, and thus controls monetary policy in that area with an agenda to maintain price stability. The application of the $45 \%-55 \%$ ordinary to development budget ratio prescribed in the

Law on Municipalities is not applied consistently and is leading to situation where some municipalities are spending more funds in the development budget at the expense of meeting their recurrent requirements.

Many municipalities are unable to adjust their expenditures during the budget year because of the belief that they are not able to make any changes to the approved budget, thus limiting their budget execution flexibility. Another key area of concern with the municipal level of governments in particular is the lack of a transfer of funds from the central to the municipal level to equalize the financial resources and service delivery capabilities across the municipalities.

It is at the centre of the European System of Central Banks, which comprehends all EU national central banks and is controlled by its General Council, consisting of the President of the ECB, who is appointed by the European Council, the Vice-President of the ECB, and the governors of the national central banks of all 28 EU member states.

Foreign companies continue to face significant challenges in entering the market, particularly in areas that touch on property rights.

Despite advancements government bureaucracy and inefficiency greatly hampers the ability to hold successful, open and transparent government tenders. They are under-equipped to handle essential tasks. These are primarily to manage transition, provide the regulatory/administrative framework for the market, establish relations with the international community and negotiate and manage aid flows. But these tasks must be carried out while re-establishing 
order and maintaining social safety nets, under conditions of budget stringency. (Dumi A. AJIS 2012)

The problem lies in policies that respond to the bond market but virtually exclude any other community interest in policy making. six key areas of consideration that taken together provide a comprehensive approach for the design and implementation of a municipal governance improvement agenda:

1. Policy Framework

2. Legal Framework

3. Service Delivery Capacities

4. Fiscal Framework

5. Inter-governmental Relations

6. Participation in Municipal Governance

Policy Framework

To develop a coherent program of building the capacity of municipalities to better deliver needed public services, it is important to frame, debate and decide critical policy options. A well-defined Policy Framework can serve as a process to engage stakeholders and as an expression of the general purpose and more specific objectives of a municipal governance program.

To be effective, a policy framework for municipal governance must be both comprehensive and strategic. The set of components below represents a fairly complete universe of the critical issues that need to be addressed in the process of developing a policy framework:

1. Building capacity to develop policies to guide a program of governance improvement

2. Clarifying/reorganizing the roles, structures and functions of Municipalities

3. Providing a comprehensive program of capacity building activities

4. Providing the resources required to do the work of Municipalities

5. Setting performance incentives/sanctions

6. Partnering to gain inter-governmental commitments needed to affect a change agenda

7. Fostering citizen participation in local governance

8. Achieving sustainability of governance improvement initiatives

It is recommended that openness in government and allowing taxpayers to understand government services are essential goals in ensuring responsible citizen oversight and providing taxpayers the opportunity to be less likely to propose restrictive initiatives or force dramatic political or management changes through the electoral process or bond referenda.

\subsection{Albanian Local Government Programs and Projects}

Refers to European Community, the difference of single states policy applied to grow the own international trade, are small. What is the real situation in states not members of European Community, like Albania, according to international business environment? The external environment includes an array of dimensions, including economic, political, legal and technological factors. The article analyses their impacts on societies and the environment, and considers the roles of governments and firms in the wider stakeholder context.

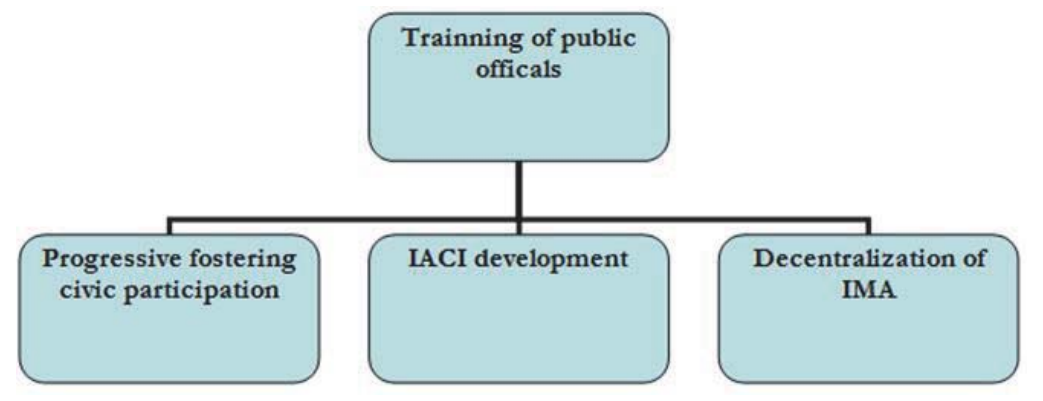

Source: European Court of Human Rights (ECHR, 2014) Hooker, Sara and Betsy Brand. 2009. Programs Support Youth on the Path to College and Beyond. Washington, DC: American Youth Policy Forum.

The Access to Information for Albanian Community Involvement program focuses on: (1) Training of public officials, local 
government representatives and civic groups on freedom of information, (2) Media outreach to inform and update the public and the government on freedom-of-information, (3) production of a freedom-of-information (FOI) website; (4) Improving mechanisms for proactive publication of government-held information; and (5) free legal counseling to citizens and community organizations on FOI. The project will reach this objective through three programmatic components: (1) local government and civil society collaboration, (2) fostering civic participation, advocacy and activism, and (3) facilitating decentralization and local fiscal autonomy. Project aims to support Albania rapprochement through developing new business partnerships and regional professional networks; engaging civil society in alliance-building to further contribute to Albania normalization; and supporting government and non-government efforts toward rapprochement with research. (SJAS 2010. College Access and Success: Education and Youth Development. Cambridge, MA: Root Cause)

2.1.2 Rule of Law Albanian Development Program core programmatic objectives include: (1) increasing the judiciary's knowledge of the European Court of Human Rights (ECHR); (2) enhancing the institutional capacity of the Independent Bar Association; (3) improving the quality of legal education; and (4) fostering an effective environment for human rights protection.

\section{Objectives}

These results suggest a product of a pull-push process between the economic forces of the bond market on one hand and politics on the other, pulling the administrative function toward efficiency in the former and democratic values of responsiveness and transparency in the latter. The problem lies in policies that respond to the bond market but virtually exclude any other community interest in policy making. It is recommended that openness in government and allowing taxpayers to understand government services are essential goals in ensuring responsible citizen oversight and providing taxpayers the opportunity to be less likely to propose restrictive initiatives or force dramatic political or management changes through the electoral process or bond referenda

Administrative changes in Albanian public policies as an obstacle to the operating foreign investment, comparison of EU like these factors: A dynamic local government leadership;

- A healthy climate of cooperation with business;

- Improving the quality of legal rules;

- Local government's investment initiatives to jumpstart the stagnant economy;

- Creative use of EU funds to implement local policy;

Efficient municipal administration;

Tab 1: Source: European Court of Human Rights (ECHR, 2014) Hooker, Sara and Betsy Brand. 2009. Programs Support Youth on the Path to College and Beyond. Washington, DC: American Youth Policy Forum.

\begin{tabular}{|l|c|c|c|c|c|c|c|c|c|}
\hline & \multicolumn{3}{|c|}{2011} & \multicolumn{3}{c|}{$\mathbf{2 0 1 2}$} & \multicolumn{3}{c|}{$\mathbf{2 0 1 3}$} \\
\hline & Female & Male & TOTAL & Female & Male & TOTAL & Female & Male & TOTAL \\
\hline TOTAL & 100.0 & 100.0 & 100.0 & 100.0 & 100.0 & 100.0 & 100.0 & 100.0 & 100.0 \\
\hline Public sector & 51.1 & 15.4 & 15.2 & 18.0 & 18.7 & 18.3 & 16.0 & 17.6 & 16.7 \\
\hline Private Sector & 36.7 & 60.4 & 46.2 & 33.3 & 55.8 & 43.4 & 33.2 & 56.5 & 43.2 \\
\hline Referenda & 48.1 & 24.1 & 37.6 & 48.7 & 25.5 & 38.3 & 50.8 & 25.9 & 40.1 \\
\hline
\end{tabular}

\section{Institutional Mission}

- Promote economic development of the city.

- Efficiently provide public services.

- Administers funds to raise the population's standard of living.

- Regulate activities such as healthfulness of district and its ecological conservation.

\section{Legal Framework}

The patchwork of formal but out-of-date legal authorities and regulations, and informal/traditional customs/arrangements/understandings about the roles and structure of local government results in a fragmented approach both in the delivery of public services and the attempts to improve local governance. A new legal framework is 
needed to set the parameters for Municipal Governance

\section{Strategic Framework}

The delegation and regulation of the responsibilities of municipalities based on the deliberations and recommendations of the policy framework Suggestions are made as to the changes that would be required to the Law of Municipalities to clarify/strengthen/make explicit the delegation of responsibilities, authorities, and sources of revenues for municipalities. The external environment includes an array of dimensions, including economic, political, legal and technological factors. The article analyses their impacts on societies and the environment, and considers the roles of governments and firms in the wider stakeholder context.

The principal arguments treated. Through its programs in the areas of anti-corruption, local governance, rule of law, alternative media, and parliamentary assistance, USAID is working with civil society and reformers within the Government of Albania to help create opportunities that helps Albania to advance the country's democratic reform both at the local and national levels. Based on an "active citizen" approach to democratic development, USAID is broadening efforts to foster greater citizen participation at the grassroots level and strengthening advocacy NGOs by providing core funding, advocacy grants and tailored technical assistance.

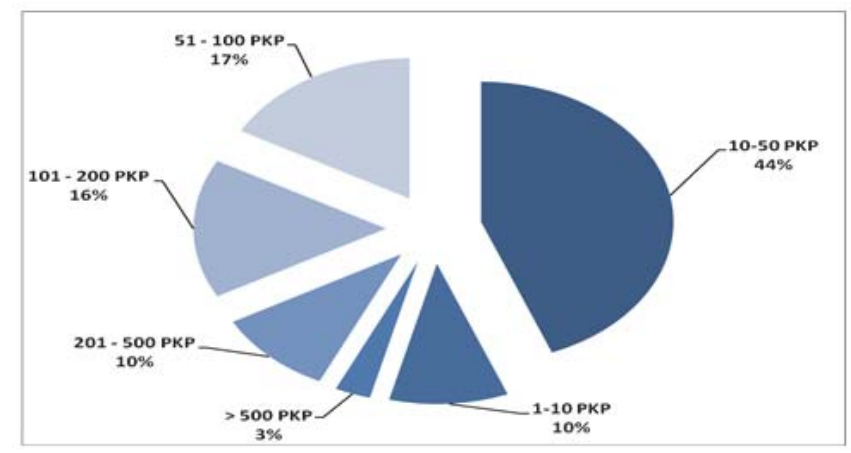

Graph 2: The indicators of the GDP, Source: B

\subsection{Analyses selected indicators for responsiveness of public administration}

The business environment may be visualized in terms of layers, beginning with the immediate internal environment within the organization, and moving outwards to the external environment surrounding the business and influencing its organization and operations. While only a few decades ago these external aspects were seen as centering on the home country of the business, the environmental horizon of business has now widened to take in a host of international forces, which interact with national and local factors.

For the larger municipalities with more substantial capacities, there is an opportunity to build an in-house capacity for an economic development office. Effective local economic development requires the active participation of three key constituencies -- the private sector, local government, and citizens. Afghanistan's economy has failed to grow and diversify in part because its local governments do not understand the role of municipalities in economic development and do not have the capacity to play that role effectively.

Service functions require better management, which in turn requires better training, structures, systems and standards. A central point of direction is needed to: provide leadership on policies governing service delivery; better manage the service operations of municipality; and, better communicate Municipal Governance Strategic Framework purposes and needs of service departments to the Mayor, Council (when they are elected) and to the public. The introduction of a Managing Director for Service Delivery on performance contract, and professionally trained and certified, could ensure a higher level of service.

Tensions exist between an organization and the external forces that impact on it, from local through to international, and these tensions are reflected in its internal environment.

For this, when we think of international business, we tend to think of large multinationals, but most of the world's businesses are very much smaller, and, increasingly, these smaller firms are becoming international in their outlook. Nowadays, thanks to advances in communication technology and transport, it is easier for companies to expand a variety 
of business activities across national borders. A large American corporation such as IBM may seem to have very little in common with a family-run firm in Tirana that selling its products or purchasing raw materials abroad, and go on to producing its products abroad. Even if their answers on how to achieve a smooth-running and efficient organization and how to satisfy the needs of customers may be different, both companies in their own way will affronting universal issues.

Like we know in the past the most important factors which influenced the firms were cultural and social, legal and technological factors. Now the factors which compose the economic policy and influenced international environment are not so unpredictable. The problem is that are complicated for the different decision making stakeholders at a time of a stagnant economy.

\section{Methodology}

From the interviews, it is clear that role confusion exists between the various organs within municipalities. This has lead to uncertainty and turf battles, shifting the energy of the council to technical issues and impeding efficient service delivery. Municipalities have not been sufficiently able to design and implement role divisions and agree on workable protocols. Local government legislation establishes various organs within the municipality and broadly defines the functions of these organs. Capacity Building for Managers

Management training is needed in a variety of capacities, including but not limited to:

1. Planning: Deciding what must be done, when, and by whom;

2. Organizing: Scheduling the effective use of resources - people, materials, and equipment to implement plans;

3. Leading: Influencing the actions of individuals and groups in order to obtain the desired results;

4. Team-Building: Developing your workers into a cohesive team; fostering a sense of independence and partnership among your work group;

5. Decision-making: Providing workers with the opportunity to make contributions and feel a part of the decisionmaking process; exhibiting both the firmness of decisive action and decision-making flexibility depending on the situation;

6. Problem-Solving: Identifying problems, gathering and analyzing relevant facts, and selecting best alternatives; ability to cope with complexity;

7. Coordinating: Building and maintaining good relations with the public; working cooperatively with other agencies and departments;

\subsection{The real situation of financial sector in Albania}

It also creates various instruments for accountability and oversight. Importantly, municipalities themselves must define the precise roles of their organs in delegations and terms of reference. These role definitions, terms of reference and instruments of accountability are intended to produce clear and sound internal municipal governance arrangements. This, in turn, is meant to define and shape the relationships within the municipal council and between the council and the administration.

\subsection{The international economic policy in Albania}

The research methodology used to complete this article is that to compare the latest international economic policies to respond to different features present or not in them. To pursue this purpose we will use as a reliable research sources such as the European community, the Ministry of Economy of Albania, etc. Albanian companies act in an environment that is more or less favorable to them. The environment is significantly limited by the institutional framework that the rules of the game and is controlled by public administration and is responsive to the needs of foreign companies.

In the empirical part of the paper, we analyze selected indicators for responsiveness of the public administration in selected Albanian programs, compared European Union (EU).

\subsection{Public Debt and Albanian Situation}

Analyzing the relationship between economic shocks and public debt that is having lately the European Community (we refer in particular to the crisis of the GDP of the two member states like Greece and Italy) budgeting decisions in the context of local economic shocks reveal the local fiscal policy priorities. The analysis of Albanian incomes, finds that current expenditure paths are more influential when making cuts than when expanding budgets. 
H2. Public Strategies employees strive to support and improve the communities in which they live and work.

The government support programs that help those in need who strive to provide for their families; and provide the youth of the community with the tools necessary to become leaders. Also focus on two primary areas to ensure the company provides meaningful contributions to the community. Our corporate contributions of time and money go to promoting philanthropy and to youth leadership development through initiatives that produce measurable outcomes and sustainable results in these two areas.

\section{Conclusions and Recommendation}

Administrative changes in Albanian public policies as an obstacle to the operating foreign investments, comparison of EU are progressed in Albania like as:

- Developing;

- International investments founds;

- Entrepreneurship ambition;

- Marshalling resources to exploit business opportunity;

- State regulatory statistical and tax reporting.

Local communities are also seen to employ some short-term use of reserve funds when facing negative expenditure pressures, but these funds are not used to completely prevent expenditure cuts. Furthermore, communities do not use debt as a mitigating response to external tax base pressures, but instead alter expenditure patterns. Using the EU measurements and assessment of different areas of the business, namely the production of goods and services, can take place smoothly in Albania. PSI worked closely with high-level public officials and community leaders and provided critical guidance and strategic planning. On an ongoing basis, PSI continues to adapt to: the changing needs of the communities we serve, legislative and administrative directives, research findings and promising practices from the field. These efforts include:

- Providing customized training and learning opportunities for partners;

- Managing the daily activities of project staff;

- Monitoring large-scale project implementation benchmarks;

- Monitoring the new opportunities of developing and LC of new business;

- Manage the human resources, youth and women.

Additionally, PSI conducts field research that may lead to adjustments to the program in order to meet greater project goals. This has resulted in a high level of trust with state officials and more effective service delivery because program adjustments are made in a timely manner.

\section{Results and Profits from this Research}

Entrepreneurship ambition has worked to support changes in Albanian law that would offer anti-discrimination protections in keeping with international standards. The another point of administrative changes in Albanian public policies as an obstacle to the operating foreign investments, comparison of EU is: (1) International investments contributed to the improvement of Albania's financial regulatory environment which has strengthened public confidence in the banking system and has provided a more secure, efficient and transparent financial system to meet the credit, savings and insurance needs of businesses and individuals.

\section{Results of Paper Research}

Local government legislation establishes various organs within the municipality and broadly defines the functions of these organs. It also creates various instruments for accountability and oversight. Importantly, municipalities themselves must define the precise roles of their organs in delegations and terms of reference. These role definitions, terms of reference and instruments of accountability are intended to produce clear and sound internal municipal governance arrangements. This, in turn, is meant to define and shape the relationships within the municipal council and between the council and the administration. Whatever cannot be solved in strictly institutional or legal terms needs to be solved through agreed protocols, gentleman's agreements and working arrangements.

The result is a carefully crafted system of governance and oversight whose success is dependent on all constituent parts working in sync. Practically, if one component of the system is deficient, it has a detrimental knock-on effect which 
ultimately impacts municipal service delivery.

From the interviews, it is clear that role confusion exists between the various organs within municipalities. This has lead to uncertainty and turf battles, shifting the energy of the council to technical issues and impeding efficient service delivery. Municipalities have not been sufficiently able to design and implement role divisions and agree on workable protocols.

\section{References}

Burdge, R.J., P. Fricke, K. Finsterbusch, W.R. Freudenberg, R. Gramling, A. Holden, L. Llewellyn, J.S. Petterson, J. Thompson, and G. Williams. 1995. Guidelines and Principles for Social Impact Assessment. Environmental Impact and Assessment Review. 15:1143. Elsevier Science, Inc.: New York.

Bill Saporito 2006 "The fix is in at home depot "Fortune 1998 pp 73-74,79 "The discount industrys top 150 Chains p 35.The economics of public health care reform in advanced and emerging economies / editors,

Canter, L. W. 1985. Socio-economic Factors Used in Environmental Impact Studies. In Canter L.W., Impact of Growth: A Guide for Socio-economic Impact Assessment and Planning, pp. 328-394. Lewis Publishers: Chelsea, Ml.

Chadwick, A. 1995.Socio-economic Impacts 2: Social Impacts. In Morris, P. And R. Therivel, Methods of Environmental Impact Assessment, pp. 29-49. University of British Columbia Press: Vancouver.

Chenoweth, R. 1999. Integrating information technologies for citizen-based land use decision-making. College of Agricultural and Life Sciences, University of Wisconsin

Christensen, K. Social Impacts of Land Development: An Initial Approach for Estimating Impacts on Neighborhood Usages and Perceptions.

David P.Schultz" The top 100 Specialty Stores August 1990 pp 9-17 Exec 100 "p 40 